\title{
Vitamin D and Glomerulonephritis
}

\author{
Guido Gembillo ${ }^{1,2, *(\mathbb{D}}$, Rossella Siligato ${ }^{1}\left(\mathbb{D}\right.$, Michela Amatruda $^{3}$, Giovanni Conti ${ }^{3}\left(\mathbb{C}\right.$ and Domenico Santoro $^{1}(\mathbb{D})$ \\ 1 Unit of Nephrology and Dialysis, Department of Clinical and Experimental Medicine, University of Messina, \\ 98125 Messina, Italy; rossellasiligato@gmail.com (R.S.); santisi@hotmail.com (D.S.) \\ 2 Department of Biomedical, Dental, Morphological and Functional Imaging Sciences, University of Messina, \\ 98125 Messina, Italy \\ 3 Unit of Pediatric Nephrology and Rheumatology, University of Messina, 98125 Messina, Italy; \\ michela.amatruda@gmail.com (M.A.); giovanniconti@hotmail.com (G.C.) \\ * Correspondence: guidogembillo@live.it
}

\section{check for}

updates

Citation: Gembillo, G.; Siligato, R.; Amatruda, M.; Conti, G.; Santoro, D. Vitamin D and Glomerulonephritis. Medicina 2021, 57, 186. https:// doi.org/10.3390/medicina57020186

Academic Editor: Francis Dumler

Received: 24 January 2021

Accepted: 16 February 2021

Published: 22 February 2021

Publisher's Note: MDPI stays neutral with regard to jurisdictional claims in published maps and institutional affiliations.

Copyright: (c) 2021 by the authors. Licensee MDPI, Basel, Switzerland. This article is an open access article distributed under the terms and conditions of the Creative Commons Attribution (CC BY) license (https:/ / creativecommons.org/licenses/by/ $4.0 /)$.

\begin{abstract}
Vitamin D presents a plethora of different functions that go beyond its role in skeletal homeostasis. It is an efficient endocrine regulator of the Renin-Angiotensin-Aldosterone System (RAAS) and erythropoiesis, exerts immunomodulatory effects, reduces the cardiovascular events and all-cause mortality. In Chronic Kidney Disease (CKD) patients, Vitamin D function is impaired; the renal hydrolyzation of its inactive form by the action of $1 \alpha$-hydroxylase declines at the same pace of reduced nephron mass. Moreover, Vitamin D major carrier, the D-binding protein (DBP), is less represented due to Nephrotic Syndrome (NS), proteinuria, and the alteration of the cubilin-megalinamnionless receptor complex in the renal proximal tubule. In Glomerulonephritis (GN), Vitamin D supplementation demonstrated to significantly reduce proteinuria and to slow kidney disease progression. It also has potent antiproliferative and immunomodulating functions, contributing to the inhibitions of kidney inflammation. Vitamin D preserves the structural integrity of the slit diaphragm guaranteeing protective effects on podocytes. Activated Vitamin D has been demonstrated to potentiate the antiproteinuric effect of RAAS inhibitors in IgA nephropathy and Lupus Nephritis, enforcing its role in the treatment of glomerulonephritis: calcitriol treatment, through Vitamin D receptor (VDR) action, can regulate the heparanase promoter activity and modulate the urokinase receptor (uPAR), guaranteeing podocyte preservation. It also controls the podocyte distribution by modulating mRNA synthesis and protein expression of nephrin and podocin. Maxalcalcitol is another promising alternative: it has about $1 / 600$ affinity to vitamin D binding protein (DBP), compared to Calcitriol, overcoming the risk of hypercalcemia, hyperphosphatemia and calcifications, and it circulates principally in unbound form with easier availability for target tissues. Doxercalciferol, as well as paricalcitol, showed a lower incidence of hypercalcemia and hypercalciuria than Calcitriol. Paricalcitol demonstrated a significant role in suppressing RAAS genes expression: it significantly decreases angiotensinogen, renin, renin receptors, and vascular endothelial growth factor (VEGF) mRNA levels, thus reducing proteinuria and renal damage. The purpose of this article is to establish the Vitamin D role on immunomodulation, inflammatory and autoimmune processes in GN.
\end{abstract}

Keywords: glomerulonephritis; vitamin D; calcitriol; glomerular disease; VDR; CKD; paricalcitol

\section{Introduction}

Glomerular diseases are the third most common cause of end-stage kidney disease (ESKD) in the United States and represent $25 \%$ of chronic kidney disease (CKD) cases in the world $[1,2]$.

In our review, we investigated the connection between Glomerulonephritis (GN) and one of the most used supplements in CKD patients, Vitamin D.

The synthesis of vitamin D active form, the 1 $\alpha, 25$-dihydroxyvitamin D3, (calcitriol) takes place mostly in the kidneys by $1 \alpha$-hydroxylase (CYP27B1), but its action declines as the nephron mass declines [3]. Several mechanisms can stimulate calcitriol renal production: 
parathormone, low calcium and phosphate serum levels, while elevated phosphate and FGF23 concentrations inhibit its production.

Vitamin D shows pleiotropic effects that encompass skeletal and non-skeletal functions: its active form has the power to modulate the action of renin-angiotensin-aldosterone system (RAAS) [4], stimulate the erythropoiesis [5], can reduce the incidence of cardiovascular events in CKD patients [6], while low vitamin D levels are associated to cardiovascular and all-cause mortality [7].

Patients with renal impairment are at higher risk of Vitamin D deficiency for multiple causes: NS, diabetic nephropathy and GN can cause the loss of its major carrier, the vitamin D-binding protein (DBP); the restriction of nutrients containing Vitamin D to avoid imbalance in phosphorus absorption; the sporadic sunlight exposure [8] and the dysfunction of the cubilin-megalin-amnionless receptor complex in the renal proximal tubule [9].

The Kidney Disease Outcomes Quality Initiative (KDOQI) guidelines recommend that CKD patients who have vitamin D insufficiency $(<30 \mathrm{ng} / \mathrm{mL})$ should receive vitamin $D$ supplementation [10].

Vitamin D deficiency is a diffuse issue with high prevalence in CKD, but the best form and posology to prevent and slow the CKD progression and prevent the onset of GN manifestations is still on debate [11].

The primary biomarker of vitamin D status is represented by serum $25(\mathrm{OH}) \mathrm{D}$ because it reflects both dietary and ultraviolet radiation influence, presents a longer half-life compared to the active form 1,25(OH)2D and can be measured accurately and reliably. In patients with NS or proteinuric kidney diseases, determination of free 25(OH)D should be preferred to total 25(OH)D levels to diagnose Vitamin D deficiency and establish the therapy [12].

Vitamin D and its receptor (VDR) modulation have been demonstrated to lessen severity of proteinuria in patients with renal impairment, one of GN's main features [13]. VDR are directly regulated using active Vitamin D such Calcitriol, that also modulates the transcription of several Vitamin D-dependent genes [14].

The best strategies for a correct Vitamin D regulation in CKD and GN are still in discussion, the number of compounds that can be selected for this purpose is rising through the years.

Calcitriol activates VDR directly with an affinity three times higher than that of the Vitamin D analog Paricalcitol, with a ten-times stronger calcemic and phosphatemic power [15]. Doxercalciferol presents similar effects compared with Calcitriol [16], but needs a further hepatic metabolization to be activated. This intermediate step makes Doxercalciferol potentially more modulable compared to the activated form of Vitamin D. This compound is more structurally similar to Vitamin D2, the plant-derived version of Vitamin $\mathrm{D}$, than with the animal-derived version. The Vitamin D3 equivalent of Doxercalciferol is the Alphacalcidol, that is also hydrolysed by the liver in a kidney-independent pathway for its activation.

Vitamin D mimetics such Paricalcitol and Maxacalcitol exerts a milder calcemic effect than Vitamin D active forms. Their bioavailability rises to peak levels and operates on the target tissue following rapid deactivation [17]. This class of drugs decreases the serum levels of intrinsic $1 \alpha, 25(\mathrm{OH})_{2} \mathrm{D}$, while Vitamin $\mathrm{D}$ analogues increases them. Maxacalcitol structurally differs from Calcitriol by the substitution of an oxygen for C22. This modification leads to a reduced affinity of Maxacalcitol for VDR and DBP, guaranteeing a better clearance of this compound [18].

Large comparative studies on different classes of Vitamin D analogs and Vitamin $\mathrm{D}$ mimetics conducted in CKD and GN populations are needed to establish the best pharmacological strategies.

Cholecalciferol administration seems to ameliorate albuminuria in CKD patients, even if the data in literature are not conclusive: Molina et al. [19] treated 101 non-dialysis CKD patients with $666 \mathrm{IU} /$ day oral cholecalciferol, with urinary albumin-to-creatinine ratio 
(uACR) decreasing from 284 (189-425) to $167 \mathrm{mg} / \mathrm{g}$ (105-266) at 6 months (geometric mean with $95 \%$ CI, $p<0.001$ ).

$\mathrm{Wu}$ et al. [20] demonstrated that an oral dose of calcitriol ( $0.25 \mu \mathrm{g}$, three times weekly) significantly reduced proteinuria in CKD patients at 8, 16 and 24 weeks of treatment ( $p<0.05$ vs. baseline). A dosage of $0.5 \mu \mathrm{g}$ calcitriol twice a week has shown efficacy in reducing the proteinuria in patients with $\operatorname{IgA}$ nephropathy $[21,22]$ (see Section 4).

In two small randomized controlled trials (RCTs), the investigators demonstrated that patients treated with Paricalcitol had lower urinary protein-to-creatinine ratio (PCR) and 24-h albumin excretion, in comparison to placebo control [23,24].

The VITAL study [25] validated the antiproteinuric effect of the addition of $2 \mu \mathrm{g} / \mathrm{day}$ of paricalcitol to a RAAS inhibitor in diabetic patients: this synergistic effect guaranteed a reduction of residual albuminuria, ranging from $-18 \%$ to $-28 \%$ ( $p=0.014 \mathrm{vs}$. placebo). In the paricalcitol and ENdothelial fuNction in chronic kidneY disease (PENNY) study [26], $2 \mu \mathrm{g} / \mathrm{d} \times 12$ weeks of paricalcitol promoted vasodilatation of vascular smooth muscle and cardiovascular in subjects with CKD stage 3-4. Aperis et al. [27] demonstrated that 1-2 $\mu \mathrm{g}$ daily of Paricalcitol could ameliorate proteinuria in patients with glomerular damage, even if there was a better response in subjects with diabetic nephropathy compared to patients with other types of GN. Other small clinical studies have also shown the potential effects of Paricalcitol in diabetic patients with and without renal involvement [28-30].

Vitamin D deficiency is linked to a complex web of severe metabolic abnormalities including inflammation, cardiovascular insults, fibrosis that have far reaching implications for health, leading to progression of renal impairment and ESKD.

The action of the different forms of vitamin $\mathrm{D}$ can potentiate the nephroprotective effects of RAAS inhibitors, adding a precious contribution as immunomodulators and anti-inflammatory drugs [31].

\section{Vitamin D and VDR in Experimental Models of GN}

Vitamin D is an efficient endocrine regulator of the RAAS and operates predominantly as a suppressor of renin biosynthesis; on the other hand, dysregulation of VDR leads to elevated renin and angiotensin II production, subsequent hypertension and cardiac hypertrophy [32]. In the kidney, the VDR not only has a major role in the modulation of renin gene expression but is also implicated in the control of inflammation, epithelialto-mesenchymal transition, and podocyte integrity [33]. Both vitamin D and VDR are involved in the regulation of apoptosis of cultured mouse podocytes and in modulation of transforming growth factor $\beta$ (TGF $\beta$ ) via the nuclear factor $\kappa B(N F-\kappa B)$ pathway upon lipopolysaccharide stimulation [34]. In fact, vitamin D demonstrates potent antiproliferative, prodifferentiative, and immunomodulating activities, inhibiting kidney inflammation via VDR-mediated sequestration of NF- $k B$ signaling [35]. Vitamin D inhibits NFkB transactivation also through the modulation of advanced glycation end-products and their receptor (AGE-RAGE system) [36], a mechanism at the basis of progression of different kidney diseases such as diabetic nephropathy, hypertensive nephropathy, obesity-related glomerulopathy, lupus nephritis, amyloidosis, autosomal dominant polycystic kidney disease, and septic acute kidney injury [37].

Vitamin D also contributes to preserving mitochondrial morphology in the renal tissue [38], while VDR activation contributes to mitochondrial integrity, by controlling the permeability transition pore (MPTP) in a ligand-independent way [39]. Mitochondrial preservation is at the basis of cellular function for adenosine triphosphate production, modulation of $\mathrm{Ca}^{2+}$ signaling, regulating reactive oxygen species (ROS) status and oxidation-reduction reactions [40].

\subsection{Calcitriol Use in Experimental GN}

Vitamin D has a pivotal role in the kidney's filtration homeostasis and plays an essential part in podocyte preservation. Podocytes damage and the impairment of the structural integrity of the slit diaphragm have been recognized as a fundamental process in the evo- 
lution of glomerulosclerosis [41]. In particular, calcitriol preserves the structural integrity of the slit diaphragm and significantly prevents the loss of nephrin and tight junction protein-1 of rats with membranoproliferative GN [42]. It exerts an antiproliferative effect in course of compensatory growth of nephrons due to subtotal nephrectomy; this action helps to improve glomerular sclerosis and albuminuria [43]. One of its functions is the inhibition of the proliferation of mesangial cells [44] with the capacity of lowering Ki67 mRNA expression and its protein production [45]. Ki67 represents a marker of proliferation, used both as an indicator of excessive cell replication and GN's progression [46]. Calcitriol found its rationale in experimental studies on IgA nephropathy (IgAN), by the immunomodulation of T helper-regulatory (Th17-Treg) cells balance and by reducing proteinuria in rats [47].

Treatment with Calcitriol can modulate the transient receptor potential cation channel C6 (TRPC6) action in mice's podocytes, while its deficiency is linked to a dysregulated action of these cation channels, podocyte foot process effacement and proteinuria [48]. These findings have also been demonstrated in diabetic rats: in the study of Zhang et al. [49] treatment with calcitriol increased VDR levels, normalized TRPC6 expression and reduced proteinuria.

Calcitriol also controls the podocyte density through a modulation of mRNA and protein expressions of nephrin and podocin, $\alpha 3 \beta 1$ integrin and $\alpha / \beta$ dystroglycan, contrasting podocyte detachment and podocytopenia [50]. Both podocyturia and nephrinuria are indicators of podocyte damage and markers of worsening of NS; their control has a pivotal role in reducing renal damage progression [51].

Calcitriol also showed a modulatory effect on the urokinase receptor (uPAR), a structure implicated in podocyte damage and development of focal segmental glomerulosclerosis (FSGS). A correct modulation of UPAR has a nephroprotective function, leading to a better control of proteinuria [52,53].

Supplementation with calcitriol has a protective function in controlling the degrading enzyme heparanase expression and subsequent reduction of proteinuria [54]. Garsen et al. [55] demonstrated that through VDR action, calcitriol treatment could regulate the heparanase promoter activity in the podocyte, guaranteeing its preservation.

Yuan et al. [56] revealed in experimental models of IgA nephropathy a positive effect of the association of tacrolimus and vitamin D in the reduction of glomerular mesangial cells hyperplasia, thickening of the glomerular basement membrane, and glomerular infiltration of inflammatory cells, in comparison to placebo and the tacrolimus alone control group. The vitamin D plus tacrolimus group showed a better modulation of NF- $\mathrm{kB} / \mathrm{TLR} 4$ pathway and reduced levels of TGF- $\beta 1$, IL-5, and IL-4.

\subsection{Paricalcitol Use in Experimental GN}

Paricalcitol exerts positive effects in the control of proteinuria, glomerulosclerosis, interstitial fibrosis, in the prevention of tubular atrophy and may contrast lymphangiogenesis, another cause of progression of renal disease $[57,58]$. It also has a cardiorenal protective effect in uremic rats by reducing myocardial fibrosis [59]. Finch et al. [60] confirmed that paricalcitol's action might be amplified with enalapril addition, decreasing interstitial infiltration of mononuclear cells and oxidative stress, and the association of both drugs is more effective than each compound alone. This pharmacological association has also been tested by Mizobuchi et al. [61] that demonstrated that the use of paricalcitol and enalapril slows the progression of renal insufficiency through the modulation of the TGF- $\beta$ signaling pathway. Based on this effect, there is the suppression of RAAS gene expression: in fact, paricalcitol lowers angiotensinogen, renin, renin receptor, and vascular endothelial growth factor mRNA status [62]. The association of paricalcitol, enalapril and atrasentan leads to even greater protective power, preventing cardiorenal damage and decreasing cardiomyocyte size to normal levels in uremic rats.

VDR stimulation through the paricalcitol also reduces proteinuria of diabetic nephropathy mice and ameliorate high-glucose-induced injury of kidneys and podocytes [63]. 


\subsection{Maxacalcitol in Experimental GN}

Maxacalcitol, also known as 22-oxa-calcitriol (OCT), prevents progression of by the control of glomerular volume and glomerular cell number, albumin excretion and rise in creatinine [64]. OCT inhibits mesangial cell proliferation, reducing the mRNA expression of Smooth Muscle Alpha-Actin (alpha-SMA), an actin isoform with a relevant role in fibrogenesis, type I and type IV collagens [65].

The positive effects of OCT on albuminuria and glomerulosclerosis have been also studied in combination with telmisartan [66]. This co-treatment provided a recovery of the slit diaphragm associated proteins with protective effects on podocytes: in fact, it contributes to the restoration of the expression of nephrin, CD2AP and podocin [67].

One of the main differences between OCT and different active forms of Vitamin D, such as calcitriol, is that the first has a lower affinity to DBP, about 1/600 compared to calcitriol [68]. This overcomes calcitriol's main side effects such as the risk of hypercalcemia, hyperphosphatemia and calcifications; OCT circulates principally as the unbound form with easier availability to target tissues. Hirata et al. [69] showed, in sub-totally nephrectomized rats, that OCT can regulate parathyroid hormone suppression with lower risk of cardiovascular calcification or worsening of residual renal function in comparison with calcitriol.

Sanai et al. [70] demonstrated that an intraperitoneal dose of $0.2 \mathrm{mcg} / \mathrm{kg}$ calcitriol three times a week, can accelerate renal deterioration in the course of experimental chronic renal failure, while OCT can attenuate renal histologic lesions. These findings are partially in contrast with the data of Matsui et al. [71] that demonstrated that both treatments with high doses of OCT $(2.0 \mu \mathrm{g} / \mathrm{kg} /$ day $)$ and high doses of Calcitriol $(0.4 \mu \mathrm{g} / \mathrm{kg} /$ day $)$ have a nephroprotective function, significantly suppressing proteinuria.

\subsection{Doxercalciferol in Experimental GN}

In obese mice, doxercalciferol was effective in decreasing proteinuria, prevented loss of podocyte, decreased mesangial expansion, extracellular matrix protein proliferation, oxidative stress, inflammation and Sterol regulatory element-binding protein 1 and 2 (SREBP-1 and -2), two critical proteins in the control of lipogenesis and mediators of kidney fibrosis [72,73]. Doxercalciferol combined with losartan has a marked power in renin and angiotensinogen suppression: in diabetic mice, it prevents albuminuria, restores glomerular filtration barrier structure and reduces glomerulosclerosis in a dose-dependent manner [74]. The promising use of this compound has been partially assessed in human models, where Doxercalciferol and Paricalcitol demonstrated a lower incidence of hypercalcemia and hypercalciuria than Calcitriol [75].

\section{Vitamin D in Children with CKD}

The importance of appropriate Vitamin D status for kidney outcomes in children has origins during pregnancy: in fact, maternal $25(\mathrm{OH}) \mathrm{D}$ levels during pregnancy may influence offspring renal outcomes [76].

Adequate Vitamin D levels in children are associated with a better control of anemia, renal osteodystrophy, secondary hyperparathyroidism, with normalization of Klotho and sclerostin [77,78]. In an analysis of bone metabolism markers in 556 pediatric CKD patients, $25(\mathrm{OH}) \mathrm{D}$ levels and serum sclerostin has been demonstrated to be positively associated with a subsequent better control of osteoblast differentiation, proliferation, and activity and reduced osteoblastic bone formation [79].

Most of all, Vitamin D's preserved function seems to reduce the proteinuria and progression of the renal disease [80]. Despite its pivotal role in renal and systemic homeostasis, low levels of Vitamin D are still a major problem in children with GN; at the same time, Vitamin D intoxication represents a rare but insidious complication of iatrogenic supplementation, leading to hypercalcemia and renal, cardiac, and neurological consequences [81]. 
Vitamin D deficiency is more common in children and adolescents with late-stage CKD. Vitamin D levels are lower in hypoalbuminemic chilidren and in those with FSGS. In this population, lower $25(\mathrm{OH}) \mathrm{D}$ concentrations is also associated with lower circulating $1,25(\mathrm{OH})_{2} \mathrm{D}$ concentration [82].

The European Society for Paediatric Nephrology Chronic Kidney Disease Mineral and Bone Disorders and Dialysis Working Groups suggest the use of native Vitamin D for the treatment of Vitamin D deficiency in children with CKD Stages 2-5D with serum 25(OH)D concentrations below $30 \mathrm{ng} / \mathrm{mL}$ [83].

A post hoc analysis on 167 children with CKD from the ESCAPE study showed that $25(\mathrm{OH}) \mathrm{D}$ levels $\geq 20 \mathrm{ng} / \mathrm{mL}$ are associated with more remarkable kidney function preservation [84]. This value is in line with the Pediatric Endocrine Society and the American Academy of Pediatrics, which established a $25(\mathrm{OH}) \mathrm{D}$ threshold of $>20 \mathrm{ng} / \mathrm{mL}$ as sufficiency in children $[85,86]$.

\subsection{Vitamin D in Children with Idiopathic Nephrotic Syndrome}

The Idiopathic NS is a very common issue in children, with an incidence of is 1.15-16.9 per 100,000 children, depending on ethnicity and country [87].

Nielsen et al. [88] in their study underlined how Vitamin D was insufficient in 93\% of pediatric patients at diagnosis of NS. In the study of Pańczyk-Tomaszewska et al. [89], on children with GN, 39\% had a deficiency or insufficiency. Zaniew et al. [90] reported a vitamin D deficiency in $16 \%$ and vitamin D insufficiency in $75 \%$ of children with steroidtreated glomerulopathies, notwithstanding the use of vitamin D supplementation in $82 \%$ of the patients.

The treatment with vitamin $\mathrm{D}$ and the modulation of its receptor in both adults and children has a central role for immune checkpoint control, being crucial for self-tolerance and the prevention of autoimmunity process based on the most forms of primary and secondary GN. Calcitriol regulates the proliferation of murine and human T cells, producing T cell cytokines, IFN- $\gamma$, and IL-17 while inducing IL-4 [91].

1-hydroxyvitamin D3 use in children with both GN and low number of T-lymphocytes in the peripheral blood has been associated with this parameter's normalization [92]. In fact, T cells are vitamin $\mathrm{D}$ targets due to the expression of the VDR, inducing autocrine calcitriol following activation. Moreover, VDR is implicated in developing two cell types, Natural Killer T cells and CD8 $\alpha \alpha$ T cells, which inhibit autoimmune uncontrolled processes [93].

Despite the central role of an adequate Vitamin D status in children with GN is well known, the incidence of its deficiency is still high and proper strategies on its correction should be improved.

\subsection{Vitamin D-Binding Protein in Children with GN}

A pivotal role in vitamin $\mathrm{D}$ biodisponibility is played by the vitamin D-binding protein (DBP), transporting $85-90 \%$ of circulating vitamin D metabolites [94]. In children has been demonstrated that DBP genetic variability affects correlations between vitamin $\mathrm{D}$ intake and the clinical measurement of vitamin D status and serum concentrations of its metabolites [95]. Madden et al. [96] showed that critically ill children present low DBP, which is translated not only in a lower biodisponibility of vitamin D and its urinary excretion [97], but also into a lower production of the antimicrobial peptide cathelicidin [98] and higher rate of multiorgan disfunction onset [99].

Urinary Vitamin D-binding protein (uVDBP) has been used as a biomarker of SteroidResistant Nephrotic Syndrome (SRNS) in children: its levels were significantly higher $(p<0.001)$ in subjects with SRNS $(13,659 \mathrm{ng} / \mathrm{mL}$, interquartile range [IQR] 477-22,979) than in patients with Steroid-Sensitive Nephrotic Syndrome (SSNS) (94 ng/mL, IQR 53202) [100].

uVDBP has also been tested, in a panel of biomarkers, to identify steroid resistance in the most common glomerular disorder of childhood, the idiopathic nephrotic syndrome (INS). uVDBP independently categorized SRNS vs. SSNS, without relation to proteinuria 
(AUC, $0.87, p<0.0002$ ) [101]. Choudhary et al. [102] also confirmed the diagnostic utility of $\mathrm{UVDBP}$ as a marker of steroid responsiveness in children with ISN: it was significantly higher $(p<0.001)$ in patients with SRNS $(701.12 \pm 371.64 \mathrm{ng} / \mathrm{mL})$ than in patients with SSNS $(252.87 \pm 66.34 \mathrm{ng} / \mathrm{mL})$ in comparison to normal controls $(34.74 \pm 14.10 \mathrm{ng} / \mathrm{mL})$.

One possible process can be linked to the chronic tubular injury and the dysregulation of intact megalin and cubilin receptors. These molecules guarantee the reabsorption of the filtered DBP in the proximal tubule (PT), with a feedback mechanism, where calcitriol is transported into the human PT epithelium via megalin-mediated endocytosis while bound to DBP [103]. This mechanism is compromised in NS and tubular injury, where the endocytic pathway's essential components are altered [104].

\subsection{Vitamin D Receptor Polymorphism in Children with GN}

Another essential component of the vitamin D pathway in GN is the VDR activity. VDR has a major role in the prevention of kidney injury by different mechanisms, such as modulation of RAAS activation, hearth diseases, anti-inflammatory role, inhibition of renal fibrogenesis, restoration of mitochondrial function, suppression of autoimmunity and renal cell apoptosis [105-108]. VDR gene BsmI polymorphism bb genotype is positively linked to NS development [109] and pyelonephritis [110].

Jafar et al. [111] studied four polymorphic sites, FokI, ApaI, TaqI and BsmI, among children with INS: they found a significant association for aa of ApaI, BB of BsmI, and ff of FokI, with INS, but no association with the polymorphic sites for TaqI. The combination of the genotypes ff of FokI and BB of BsmI of VDR was associated with a 3.5 increased risk fold. These results are not in line with Al-Eisa et al. [112] that found that both the VDR genetic polymorphisms TaqI and Apal are not associated with childhood INS. The available data from clinical trials of Vitamin D Receptor Polymorphism in Children with GN are still inconclusive.

\section{Vitamin D in IgA Nephropathy}

IgAN is the most common primary GN worldwide and a significant ESRD cause [113]. Moreover, Vitamin D deficiency is linked to poorer clinical outcomes and more severe IgAN pathological features [114].

The adequate control of proteinuria in IgA patients is essential and represents an indicator of favorable outcome in delaying the disease's progression [115]. KDIGO guidelines recommend the use of angiotensin-converting enzyme inhibitors (ACEi) or angiotensin receptor blockers (ARB) in IgAN patients with proteinuria above $1.0 \mathrm{~g} /$ day [116]. The association of these antihypertensive treatments with Vitamin $\mathrm{D}$ for control of proteinuria has been investigated and confirmed in several studies [117,118].

Activated vitamin $\mathrm{D}$ has been demonstrated to potentiate the antiproteinuric effect of ARB in IgA nephropathy: patients who received $0.5 \mu \mathrm{g} /$ day of calcitriol plus Valsartan had a significative proteinuria decrement (from $2.39 \pm 0.77$ to $1.43 \pm 0.57 \mathrm{~g} / 24 \mathrm{~h}, p<0.01$ ) in comparison to the group treated only with ARB (from $2.46 \pm 0.81$ to $1.78 \pm 0.60 \mathrm{~g} / 24 \mathrm{~h}$, $p<0.05)$ [119].

Szeto et al. [120] showed that Calcitriol may significantly reduce proteinuria and urine PCR decreasing TGF- $\beta$ level in 10 patients with IgAN with persistent proteinuria notwithstanding the use of ACEi and ARB.

These results have been confirmed by the meta-analysis of randomized trial of Deng et al. [121], which demonstrated that Calcitriol contributes significantly to reduce proteinuria (standard mean difference $-1.49,95 \%$ CI $(-2.37,-0.62) ; p=0.0008)$, with only mild side effects.

In IgAN patients, Calcitriol supplementation showed a stabilization of cardiac autonomic tone in response to an acute physiological stressor, representing a potential preventive cardiovascular therapy in this population [122]. Calcitriol's cardioprotective role confirms the findings of previous studies that indicate that this compound can modulate the cardiac autonomic system through the enhancement of electrophysiological $\beta$-adrenergic 
signaling between cardiac myocytes [123] or, through VDR control, it can modulate myocardial contractility by the regulation of calcium flux [124].

Moreover, DBPs can be used to evaluate urinary proteome, representing a promising predictive biomarker of responsiveness of IgAN therapy. uVDBPs have $65 \%$ sensitivity, $75 \%$ accuracy and $85 \%$ specificity predicting irbesartan non-responsiveness in IgAN patients [125].

Genetic causes guide the occurrence and progression of IgAN: Shi et al. [126] demonstrated that IgAN progression in subjects with moderate and high genetic risk was 2.12and 3.61-fold higher than in those with low genetic risk. In support of this concept, Mo et al. [127] studied the relationship between VDR FokI single nucleotide polymorphism and renal function in IgA patients: the subjects presenting VDR FokI TT genotype had an increased risk of renal dysfunction, demonstrating a potential utility in prediction of the progression of the disease. VDR polymorphisms may aggravate IgAN by inhibiting active vitamin D's protective role, worsening endothelial cells dysfunction, mesangial cell proliferation, and podocyte and tubulointerstitial damage [128]. In this context, VDR influence and its polymorphisms should be adequately and broadly investigated to understand better its predictive role and influence in the progression of IgAN.

\section{Vitamin D in Lupus Nephritis}

Lupus nephritis (LN) is clinically manifest in 50 to $75 \%$ of patients with systemic lupus erythematosus (SLE), and 10\% of patients with LN will develop ESRD [129]. The majority of SLE patients have suboptimal vitamin D levels; factors that can contribute to this deficit are associated with renal impairment, and the sun protection measures adopted to avoid SLE flares [130]. Vitamin D in patients with LN is significantly lower than in subjects with inactive SLE or active SLE but without LN [131]. These findings are also confirmed in pediatric patients with LN: serum vitamin D levels are inversely correlated with SLE disease activity and LN presence during flares [132]. In vitro experiments showed a nephroprotective role of vitamin D versus LN autoantibodies: serum $25(\mathrm{OH}) 2 \mathrm{D} 3$ was linked with downregulation of aberrant autophagy of podocytes [133].

Pérez-Ferro et al. [134] associated circulating major histocompatibility complex class I-related chain A (MHC-MICA) levels to a subgroup of SLE patients with low vitamin $\mathrm{D}$, innate activation of T cells and LN. This supports the immunomodulatory theory on vitamin $\mathrm{D}$, whom deficit can be linked to the control of cytolytic mechanisms induced by innate immune triggers. Their patients presented an inverse relationship between vitamin D levels and proteinuria $(\rho=-0.398, p=0.036)$, and a significant correlation with T-in cell MICA gene expression $(\rho=0.526, p=0.008)$. Vitamin D can help restore the immune system's homeostasis during SLE flares and contribute to slow LN progression.

VDR stimulation by active vitamin D evokes immune tolerance and promotes the expression of anti-proliferative/pro-apoptotic molecules, and immune cells stimulate the upregulation of VDR transcription [135]. VDR activation stimulates immune cells with intracrine, autocrine, and/or paracrine effects and stimulate different components of both innate and adaptive immunity pathways [136]. In LN, VDR expression promotes regulatory T-cells expansion and reduces the proliferation of Th1 cells, Th17 cells, memory B cells and auto-antibodies, at the basis of SLE [137]. VDR polymorphisms can significantly increase SLE activity and LN related complications [138].

In a study on female Egyptian SLE patients, Emerah et al. [139] found that there is a tight association of VDR ApaI AA, BsmI BB, and FokI FF genotypes with LN and higher SLE activity scores. These findings are in line with the results of Mostowska et al. [140] in Polish SLE patients: subjects with the Ff and FF genotypes of the FokI VDR polymorphism presented a major risk of developing kidney disease. Azab et al. [141] also evaluated VDR polymorphism recurrence in the Egyptian population, this time in children and adolescents. In their study there was a significant association between VDR BsmI BB genotype with LN ( $p=0.001)$. Imam et al. [142] studied FokI polymorphism in the same population target, finding a significant association between VDR FokI FF genotype with LN $(p=0.002)$. 
In an Indian cohort of SLE patients TaqI, BsmI and ApaI polymorphisms did not significantly associate with LN but interestingly, patients with homozygous polymorphism for FokI (ff) and with vitamin D deficiency were exclusively observed among LN cases [143].

In Han Chinese population, VDR gene BsmI polymorphism B allele is associated with LN $(p=0.027)$ and also with production of anti-nucleosome antibodies $(p=0.037)$ [144]. These results are confirmed by a study of Ozaki et al. [109] on the Japanese SLE population: they revealed that bb genotype of BsmI polymorphism is correlated with NS and renal dysfunction $(p=0.0304)$.

Sun et al. [145] studied VDR tissue expression in renal biopsies of LN patients, founding that it was less represented in renal tubular cells $(p<0.001)$ in LN patients and negatively correlated with activity index $(\mathrm{r}=-0.548, p=0.012)$ compared to the control group. DBP has a promising role in nephroprotective strategies in LN patients; low baseline levels of uVDBP are associated with better LN flares outcomes [146].

Go et al. [147] demonstrated that uVDBP is significantly related to proteinuria severity $(p<0.001)$ and renal SLE Disease Activity Index $(p<0.001)$. DBP represented a significant risk factor (hazard ratio 9.627, 95\% confidence interval 1.698 to $54.571, p=0.011$ ) for the onset of proteinuric flare in SLE subjects without proteinuria.

\section{Conclusions}

Vitamin D presents a plethora of different functions that goes beyond its role in skeletal homeostasis.

In GN, Vitamin D supplementation demonstrated a significant reduction of proteinuria and beneficial effects in slowing progression of CKD, exerting potent antiproliferative and immunomodulating functions and contributing to inhibition of kidney inflammation. Vitamin D preserves the structural integrity of the slit diaphragm, significantly prevents the loss of nephrin, podocin and tight junction proteins, but also regulates VDR activation, directly reducing renal impairment and guaranteeing many pleiotropic effects [148]. Moreover, activated vitamin $\mathrm{D}$ has been demonstrated to potentiate the antiproteinuric effect of RAAS inhibitors in IgAN and LN, enforcing its role in GN treatment. The best strategy to reduce the proteinuria and contrast $\mathrm{GN}$ is still to be defined; the results are promising but still not conclusive.

Therefore, we suggest that studies on immunomodulation, inflammatory processes, autoimmune processes, either in vitro on cell cultures or in vivo using lab animals and prospective long-term and larger RCTs, should be conducted to determine all the effects of Vitamin D in these pathologies.

Author Contributions: Literature search G.G., R.S.; conceptualization G.G., D.S., G.C.; bias assessment M.A.; study selection G.G., D.S.; manuscript drafting G.G., R.S., G.C.; critical revision and approval of the manuscript, all authors. All authors have read and agreed to the published version of the manuscript.

Funding: This research received no external funding.

Institutional Review Board Statement: Not applicable.

Informed Consent Statement: Not applicable.

Data Availability Statement: Data sharing is not applicable to this article as no new data were created or analyzed in this study.

Conflicts of Interest: The authors declare no conflict of interest.

\section{References}

1. Floege, J.; Amann, K. Primary glomerulonephritides. Lancet 2016, 387, 2036-2048. [CrossRef]

2. Saran, R.; Robinson, B.; Abbott, K.C.; Agodoa, L.Y.; Albertus, P.; Ayanian, J.; Balkrishnan, R.; Bragg-Gresham, J.; Cao, J.; Chen, J.L.T.; et al. US Renal Data System 2016 Annual Data Report: Epidemiology of Kidney Disease in the United States. Am. J. Kidney Dis. 2017, 69 (3 Suppl. 1), 712. [CrossRef] [PubMed] 
3. Tanaka, Y.; DeLuca, H.F. Rat renal 25-hydroxyvitamin D3 1- and 24-hydroxylases: Their in vivo regulation. Am. J. Physiol. 1984, 246, E168-E173. [CrossRef] [PubMed]

4. Santoro, D.; Sebekova, K.; Teta, D.; De Nicola, L. Extraskeletal Functions of Vitamin, D. Biomed. Res. Int. 2015, $2015,294719$. [CrossRef]

5. Santoro, D.; Caccamo, D.; Lucisano, S.; Buemi, M.; Sebekova, K.; Teta, D.; De Nicola, L. Interplay of vitamin D, erythropoiesis, and the renin-angiotensin system. Biomed. Res. Int. 2015, 2015, 145828. [CrossRef]

6. Li, X.-H.; Feng, L.; Yang, Z.-H.; Liao, Y.-H. Effect of active vitamin D on cardiovascular outcomes in predialysis chronic kidney diseases: A systematic review and meta-analysis. Nephrology 2015, 20, 706-714. [CrossRef]

7. Dobnig, H.; Pilz, S.; Scharnagl, H.; Renner, W.; Seelhorst, U.; Wellnitz, B.; Maerz, W. Independent association of low serum 25-hydroxyvitamin d and 1,25-dihydroxyvitamin d levels with all-cause and cardiovascular mortality. Arch. Intern. Med. 2008, 168, 140-149. [CrossRef]

8. Dattola, A.; Silvestri, M.; Bennardo, L.; Passante, M.; Scali, E.; Patruno, C.; Nisticò, S.P. Role of Vitamins in Skin Health: A Systematic Review. Curr. Nutr. Rep. 2020, 9, 226-235. [CrossRef]

9. Gembillo, G.; Cernaro, V.; Salvo, A.; Siligato, R.; Laudani, A.; Buemi, M.; Santoro, D. Role of Vitamin D Status in Diabetic Patients with Renal Disease. Medicina 2019, 55, 273. [CrossRef]

10. Kramer, H.; Berns, J.S.; Choi, M.J.; Martin, K.; Rocco, M.V. 25-Hydroxyvitamin D Testing and Supplementation in CKD: An NKF-KDOQI Controversies Report. Am. J. Kidney Dis. 2014, 64, 499-509. [CrossRef]

11. Khurana, S.; A Bruggeman, L.; Kao, H.-Y. Nuclear hormone receptors in podocytes. Cell Biosci. 2012, 2, 33. [CrossRef]

12. Banerjee, S.; Basu, S.; Akhtar, S.; Sinha, R.; Sen, A.; Sengupta, J. Free vitamin D levels in steroid-sensitive nephrotic syndrome and healthy controls. Pediatr. Nephrol. 2020, 35, 447-454. [CrossRef]

13. De Zeeuw, D.; Remuzzi, G.; Parving, H.-H.; Keane, W.F.; Zhang, Z.; Shahinfar, S.; Snapinn, S.; Cooper, M.E.; Mitch, W.E.; Brenner, B.M. Proteinuria, a target for renoprotection in patients with type 2 diabetic nephropathy: Lessons from RENAAL. Kidney Int. 2004, 65, 2309-2320. [CrossRef]

14. Koivisto, O.; Hanel, A.; Carlberg, C. Key Vitamin D Target Genes with Functions in the Immune System. Nutrients 2020, $12,1140$. [CrossRef]

15. Monier-Faugere, M.-C.; Mawad, H.; Malluche, H.H. Opposite Effects of Calcitriol and Paricalcitol on the Parathyroid Hormone(1-84)/Large Carboxy-Terminal-Parathyroid Hormone Fragments Ratio in Patients with Stage 5 Chronic Kidney Disease. Clin. J. Am. Soc. Nephrol. 2007, 2, 1255-1260. [CrossRef]

16. Park, J.; Rhee, C.M.; Lau, W.L.; Kalantar-Zadeh, K. Clinical uses of 1-alpha-hydroxy-ergocalciferol. Curr. Vasc. Pharmacol. 2014, 12, 306-312. [CrossRef]

17. Obi, Y.; Kalantar-Zadeh, K. Yet Another Vitamin D Analogue for the Management of Secondary Hyperparathyroidism: A Triton among the Minnows? Am. J. Nephrol. 2016, 43, 221-224. [CrossRef]

18. Bikle, D.D.; Abe-Hashimoto, J.; Su, M.-J.; Felt, S.; Gibson, D.F.C.; Pillai, S. 22-Oxa Calcitriol Is a Less Potent Regulator of Keratinocyte Proliferation and Differentiation Due to Decreased Cellular Uptake and Enhanced Catabolism. J. Investig. Dermatol. 1995, 105, 693-698. [CrossRef]

19. Molina, P.; Górriz, J.L.; Molina, M.D.; Peris, A.; Beltrán, S.; Kanter, J.; Escudero, V.; Romero, R.; Pallardó, L.M. The effect of cholecalciferol for lowering albuminuria in chronic kidney disease: A prospective controlled study. Nephrol. Dial. Transplant. 2014, 29, 97-109. [CrossRef]

20. Wu, C.-C.; Liao, M.-T.; Hsiao, P.-J.; Lu, C.-L.; Hsu, Y.-J.; Lu, K.-C.; Chu, P. Antiproteinuria Effect of Calcitriol in Patients with Chronic Kidney Disease and Vitamin D Deficiency: A Randomized Controlled Study. J. Ren. Nutr. 2020, 30, 200-207. [CrossRef]

21. Rodriguez, M.; Munoz-Castaneda, J.R.; Almaden, Y. Therapeutic use of calcitriol. Curr. Vasc. Pharmacol. 2014, 12, 294-299. [CrossRef]

22. Liu, L.-J.; Lv, J.-C.; Shi, S.-F.; Chen, Y.-Q.; Zhang, H.; Wang, H.-Y. Oral Calcitriol for Reduction of Proteinuria in Patients with IgA Nephropathy: A Randomized Controlled Trial. Am. J. Kidney Dis. 2012, 59, 67-74. [CrossRef] [PubMed]

23. Fishbane, S.; Chittineni, H.; Packman, M.; Dutka, P.; Ali, N.; Durie, N. Oral paricalcitol in the treatment of patients with CKD and proteinuria: A randomized trial. Am. J. Kidney Dis. 2009, 54, 647-652. [CrossRef]

24. Alborzi, P.; Patel, N.A.; Peterson, C.; Bills, J.E.; Bekele, D.M.; Bunaye, Z.; Light, R.P.; Agarwal, R. Paricalcitol reduces albuminuria and inflammation in chronic kidney disease: A randomized double-blind pilot trial. Hypertension 2008, 52, 249-255. [CrossRef]

25. De Zeeuw, D.; Agarwal, R.; Amdahl, M.; Audhya, P.; Coyne, D.; Garimella, T.; Parving, H.-H.; Pritchett, Y.; Remuzzi, G.; Ritz, E.; et al. Selective vitamin D receptor activation with paricalcitol for reduction of albuminuria in patients with type 2 diabetes (VITAL study): A randomised controlled trial. Lancet 2010, 376, 1543-1551. [CrossRef]

26. Zoccali, C.; Curatola, G.; Panuccio, V.; Tripepi, R.; Pizzini, P.; Versace, M.; Bolignano, D.; Cutrupi, S.; Politi, R.; Tripepi, G.; et al. Paricalcitol and Endothelial Function in Chronic Kidney Disease Trial. Hypertens. 2014, 64, 1005-1011, Erratum in 2014, 64, e48. [CrossRef]

27. Aperis, G.; Paliouras, C.; Zervos, A.; Arvanitis, A.; Alivanis, P. The role of paricalcitol on proteinuria. J. Ren. Care 2011, 37, 80-84. [CrossRef]

28. De Lorenzo, A.; Salanova, L.; Bomback, A.S.; Moya, M.; Coronel, F.; Bernis, C.; A Sánchez-Tomero, J.; Álvarez, V. Oral paricalcitol as antiproteinuric agent in chronic kidney disease. Nefrologia 2013, 33, 709-715. 
29. Ekart, R.; Bevc, S.; Hojs, R.; Hojs, N. Proteinuria and Albuminuria During and After Paricalcitol Treatment in Chronic Kidney Disease Patients. J. Clin. Pharmacol. 2016, 56, 761-768. [CrossRef]

30. Brown, J.M.; Secinaro, K.; Williams, J.S.; Vaidya, A. Evaluating hormonal mechanisms of vitamin D receptor agonist therapy in diabetic kidney disease: The VALIDATE-D study. BMC Endocr. Disord. 2013, 13, 33. [CrossRef]

31. Pilz, S.; Verheyen, N.; Grübler, M.R.; Tomaschitz, A.; März, W. Vitamin D and cardiovascular disease prevention. Nat. Rev. Cardiol. 2016, 13, 404-417. [CrossRef]

32. Li, Y.C.; Qiao, G.; Uskokovic, M.; Xiang, W.; Zheng, W.; Kong, J. Vitamin D: A negative endocrine regulator of the renin-angiotensin system and blood pressure. J. Steroid Biochem. Mol. Biol. 2004, 89-90, 387-392. [CrossRef]

33. Agarwal, R. Vitamin D, proteinuria, diabetic nephropathy, and progression of CKD. Clin. J. Am. Soc. Nephrol. 2009, 4, 1523-1528. [CrossRef]

34. Xu, L.; Zhang, P.; Guan, H.; Huang, Z.; He, X.; Wan, X.; Xiao, H.; Li, Y. Vitamin D and its receptor regulate lipopolysaccharideinduced transforming growth factor- $\beta$, angiotensinogen expression and podocytes apoptosis through the nuclear factor- $\mathrm{k} B$ pathway. J. Diabetes Investig. 2016, 7, 680-688. [CrossRef]

35. Tan, X.; Wen, X.; Liu, Y. Paricalcitol inhibits renal inflammation by promoting vitamin D receptor-mediated sequestration of NF-kappaB signaling. J. Am. Soc. Nephrol. 2008, 19, 1741-1752. [CrossRef]

36. Kheirouri, S.; Alizadeh, M. Vitamin D and advanced glycation end products and their receptors. Pharmacol. Res. 2020, 158, 104879. [CrossRef]

37. Fukami, K.; Taguchi, K.; Yamagishi, S.-I.; Okuda, S. Receptor for advanced glycation endproducts and progressive kidney disease. Curr. Opin. Nephrol. Hypertens. 2015, 24, 54-60. [CrossRef]

38. García, I.M.; Altamirano, L.; Mazzei, L.; Fornés, M.; Cuello-Carrión, F.D.; Ferder, L.; Manucha, W. Vitamin D receptor-modulated Hsp70/AT1 expression may protect the kidneys of SHRs at the structural and functional levels. Cell Stress Chaperones 2013, 19, 479-491. [CrossRef]

39. Silvagno, F.; Consiglio, M.; Foglizzo, V.; Destefanis, M.; Pescarmona, G. Mitochondrial Translocation of Vitamin D Receptor Is Mediated by the Permeability Transition Pore in Human Keratinocyte Cell Line. PLoS ONE 2013, 8, e54716. [CrossRef]

40. McCarron, J.G.; Wilson, C.; Sandison, M.E.; Olson, M.L.; Girkin, J.M.; Saunter, C.; Chalmers, S. From Structure to Function: Mitochondrial Morphology, Motion and Shaping in Vascular Smooth Muscle. J. Vasc. Res. 2013, 50, 357-371. [CrossRef]

41. Wiggins, R. The spectrum of podocytopathies: A unifying view of glomerular diseases. Kidney Int. 2007, 71, 1205-1214. [CrossRef]

42. Migliori, M.; Giovannini, L.; Panichi, V.; Filippi, C.; Taccola, D.; Origlia, N.; Mannari, C.; Camussi, G. Treatment with 1, 25Dihydroxyvitamin D3 Preserves Glomerular Slit Diaphragm-Associated Protein Expression in Experimental Glomerulonephritis. Int. J. Immunopathol. Pharmacol. 2005, 18, 779-790. [CrossRef]

43. Schwarz, U.; Amann, K.; Orth, S.R.; Simonaviciene, A.; Wessels, S.; Ritz, E. Effect of 1,25(OH)2 vitamin D3 on glomerulosclerosis in subtotally nephrectomized rats. Kidney Int. 1998, 53, 1696-1705. [CrossRef] [PubMed]

44. Zhang, C.J.; Zhao, D.; Yin, X.; Zhang, H.; Ma, L.; Chen, J.P.; Liu, C.; Yang, X.P. Effects of 1,25(OH)2D3 on proliferation and apoptosis of human glomerular mesangial cells. Am. J. Transl. Res. 2016, 8, 2659-2666. [PubMed]

45. Zhao, D.; Zhang, C.-J.; Yang, R.; Chen, J.-P.; Ma, L.; Liu, G.; Yang, X.-P. Effect of 1,25(OH2D3 on the proliferation of human mesangial cells and their expression of Ki67. Genet. Mol. Res. 2017, 16. [CrossRef] [PubMed]

46. Kim, O. Immunohistochemical study of the expression of $\alpha$-smooth muscle actin and the proliferation marker Ki-67 of glomerulonephritis. J. Korean Med Sci. 2001, 16, 455-461. [CrossRef] [PubMed]

47. Zhang, X.; Wu, X.; Xiong, L.; Yi, Z.; He, Q.; He, X.; Mo, S. Role of vitamin D3 in regulation of T helper cell 17 and regulatory T-cell balance in rats with immunoglobulin a nephropathy. Iran J. Kidney Dis. 2014, 8, 363-370.

48. Sonneveld, R.; Ferrè, S.; Hoenderop, J.G.; Dijkman, H.B.; Berden, J.H.; Bindels, R.J.; Wetzels, J.F.; Van Der Vlag, J.; Nijenhuis, T. Vitamin D Down-Regulates TRPC6 Expression in Podocyte Injury and Proteinuric Glomerular Disease. Am. J. Pathol. 2013, 182, 1196-1204. [CrossRef]

49. Zhang, X.; Song, Z.; Guo, Y.; Zhou, M. The novel role of TRPC6 in vitamin D ameliorating podocyte injury in STZ-induced diabetic rats. Mol. Cell. Biochem. 2015, 399, 155-165. [CrossRef]

50. Zou, M.-S.; Yu, J.; Zhou, J.-H.; Nie, G.-M.; Ding, D.-S.; Luo, L.-M.; Xu, H.-T.; He, W.-S. 1,25-Dihydroxyvitamin D3 Ameliorates Podocytopenia in Rats with Adriamycin-induced Nephropathy. Intern. Med. 2010, 49, 2677-2686. [CrossRef]

51. Siligato, R.; Gembillo, G.; Cernaro, V.; Torre, F.; Salvo, A.; Granese, R.; Santoro, D. Maternal and Fetal Outcomes of Pregnancy in Nephrotic Syndrome Due to Primary Glomerulonephritis. Front. Med. 2020, 7, 925. [CrossRef]

52. Ma, J.; Zhang, B.; Liu, S.; Xie, S.; Yang, Y.; Ma, J.; Deng, Y.; Wang, W.; Xu, L.; Li, R.; et al. 1,25-Dihydroxyvitamin D(3) Inhibits Podocyte uPAR Expression and Reduces Proteinuria. PLoS ONE 2013, 8, e64912. [CrossRef]

53. Wei, C.; Möller, C.C.; Altintas, M.M.; Li, J.; Schwarz, K.; Zacchigna, S.; Xie, L.; Henger, A.; Schmid, H.; Rastaldi, M.P.; et al. Modification of kidney barrier function by the urokinase receptor. Nat. Med. 2008, 14, 55-63. [CrossRef] [PubMed]

54. Masola, V.; Zaza, G.; Onisto, M.; Gambaro, G. Heparanase: Another renal player controlled by vitamin D. J. Pathol. 2016, 238, 7-9. [CrossRef] [PubMed]

55. Garsen, M.; Sonneveld, R.; Rops, A.L.W.M.M.; Huntink, S.; Van Kuppevelt, T.H.; Rabelink, T.J.; Hoenderop, J.G.J.; Berden, J.H.M.; Nijenhuis, T.; Van Der Vlag, J. Vitamin D attenuates proteinuria by inhibition of heparanase expression in the podocyte. J. Pathol. 2015, 237, 472-481. [CrossRef] 
56. Yuan, D.; Fang, Z.; Sun, F.; Chang, J.; Teng, J.; Lin, S.; Liu, X. Effect of Vitamin D and Tacrolimus Combination Therapy on IgA Nephropathy. Med. Sci. Monit. 2017, 23, 3170-3177. [CrossRef]

57. Yazdani, S.; Poosti, F.; Toro, L.; Wedel, J.; Mencke, R.; Mirković, K.; De Borst, M.H.; Alexander, J.S.; Navis, G.; Van Goor, H.; et al. Vitamin D inhibits lymphangiogenesis through VDR-dependent mechanisms. Sci. Rep. 2017, 7, 44403. [CrossRef]

58. Ritter, C.; Zhang, S.; Finch, J.L.; Liapis, H.; Suarez, E.; Ferder, L.; Delmez, J.; Slatopolsky, E. Cardiac and Renal Effects of Atrasentan in Combination with Enalapril and Paricalcitol in Uremic Rats. Kidney Blood Press. Res. 2014, 39, 340-352. [CrossRef] [PubMed]

59. Panizo, S.; Barrio-Vazquez, S.; Naves-Diaz, M.; Carrillo-Lopez, N.; Rodriguez, I.; Fernandez-Vazquez, A.; Valdivielso, J.M.; Thadhani, R.; Cannata-Andia, J.B. Vitamin D receptor activation, left ventricular hypertrophy and myocardial fibrosis. Nephrol. Dial. Transplant 2013, 28, 2735-2744. [CrossRef]

60. Finch, J.L.; Suarez, E.B.; Husain, K.; Ferder, L.; Cardema, M.C.; Glenn, D.J.; Gardner, D.G.; Liapis, H.; Slatopolsky, E. Effect of combining an ACE inhibitor and a VDR activator on glomerulosclerosis, proteinuria, and renal oxidative stress in uremic rats. Am. J. Physiol. Physiol. 2012, 302, F141-F149. [CrossRef]

61. Mizobuchi, M.; Morrissey, J.; Finch, J.L.; Martin, D.R.; Liapis, H.; Akizawa, T.; Slatopolsky, E. Combination Therapy with an Angiotensin-Converting Enzyme Inhibitor and a Vitamin D Analog Suppresses the Progression of Renal Insufficiency in Uremic Rats. J. Am. Soc. Nephrol. 2007, 18, 1796-1806. [CrossRef]

62. Freundlich, M.; Quiroz, Y.; Zhang, Z.; Zhang, Y.; Bravo, Y.; Weisinger, J.R.; Li, Y.C.; Rodriguez-Iturbe, B. Suppression of renin-angiotensin gene expression in the kidney by paricalcitol. Kidney Int. 2008, 74, 1394-1402. [CrossRef]

63. Guo, J.; Lu, C.; Zhang, F.; Yu, H.; Zhou, M.; He, M.; Wang, C.; Zhao, Z.; Liu, Z. VDR Activation Reduces Proteinuria and High-Glucose-Induced Injury of Kidneys and Podocytes by Regulating Wnt Signaling Pathway. Cell. Physiol. Biochem. 2020, 43, 39-51, Erratum in 2020, 54, 1091. [CrossRef] [PubMed]

64. Hirata, M.; Makibayashi, K.; Katsumata, K.; Kusano, K.; Watanabe, T.; Fukushima, N.; Doi, T. 22-Oxacalcitriol prevents progressive glomerulosclerosis without adversely affecting calcium and phosphorus metabolism in subtotally nephrectomized rats. Nephrol. Dial. Transplant. 2002, 17, 2132-2137. [CrossRef] [PubMed]

65. Makibayashi, K.; Tatematsu, M.; Hirata, M.; Fukushima, N.; Kusano, K.; Ohashi, S.; Abe, H.; Kuze, K.; Fukatsu, A.; Kita, T.; et al. A Vitamin D Analog Ameliorates Glomerular Injury on Rat Glomerulonephritis. Am. J. Pathol. 2001, 158, 1733-1741. [CrossRef]

66. Jeong, K.H.; Asanuma, K.; Lydia, A.; Takagi, M.; Asao, R.; Kodama, F.; Asanuma, E.; Tomino, Y. Combination Therapy with Telmisartan and Oxacalcitriol Suppresses the Progression of Murine Adriamycin Nephropathy. Nephron 2015, 129, 143-154. [CrossRef]

67. Lydia, A.; Asanuma, K.; Nonaka, K.; Takagi, M.; Jeong, K.-H.; Kodama, F.; Asao, R.; Asanuma, E.; Prodjosudjadi, W.; Tomino, Y. Effects of 22-Oxa-Calcitriol on Podocyte Injury in Adriamycin-Induced Nephrosis. Am. J. Nephrol. 2012, 35, 58-68. [CrossRef] [PubMed]

68. Brown, A.J.; Finchi, J.; Grieff, M.; Ritter, C.; Kubodera, N.; Nishii, Y.; Slatopolsky, E. The mechanism for the disparate actions of calcit-riol and 22-oxacalcitriol in the intestine. Endocrinology 1993, 133, 1158-1164. [CrossRef] [PubMed]

69. Hirata, M.; Katsumata, K.; Endo, K.; Fukushima, N.; Ohkawa, H.; Fukagawa, M. In subtotally nephrectomized rats 22-oxacalcitriol suppresses parathyroid hormone with less risk of cardiovascular calcification or deterioration of residual renal function than 1,25(OH)2 vitamin D3. Nephrol. Dial. Transplant. 2003, 18, 1770-1776. [CrossRef]

70. Sanai, T.; Tokumoto, M.; Hirano, T.; Okuda, S. Different effects of 22-oxacalcitriol and calcitriol on the course of experimental chronic renal failure. J. Lab. Clin. Med. 2002, 140, 242-249. [CrossRef]

71. Matsui, I.; Hamano, T.; Tomida, K.; Inoue, K.; Takabatake, Y.; Nagasawa, Y.; Kawada, N.; Ito, T.; Kawachi, H.; Rakugi, H.; et al. Active vitamin D and its analogue, 22-oxacalcitriol, ameliorate puromycin aminonucleoside-induced nephrosis in rats. Nephrol. Dial. Transplant. 2009, 24, 2354-2361. [CrossRef] [PubMed]

72. Wang, X.X.; Jiang, T.; Shen, Y.; Santamaria, H.; Solis, N.; Arbeeny, C.; Levi, M. Vitamin D receptor agonist doxercalciferol modulates dietary fat-induced renal disease and renal lipid metabolism. Am. J. Physiol. Physiol. 2011, 300, F801-F810. [CrossRef]

73. Dorotea, D.; Koya, D.; Ha, H. Recent Insights Into SREBP as a Direct Mediator of Kidney Fibrosis via Lipid-Independent Pathways. Front. Pharmacol. 2020, 11. [CrossRef]

74. Zhang, Y.; Deb, D.K.; Kong, J.; Ning, G.; Wang, Y.; Li, G.; Chen, Y.; Zhang, Z.; Strugnell, S.; Sabbagh, Y.; et al. Long-term therapeutic effect of vitamin D analog doxercalciferol on diabetic nephropathy: Strong synergism with AT1 receptor antagonist. Am. J. Physiol. Physiol. 2009, 297, F791-F801. [CrossRef] [PubMed]

75. Gallagher, J.; Bishop, C.W.; Knutson, J.C.; Mazess, R.B.; DeLuca, H.F. Effects of increasing doses of $1 \alpha$-hydroxyvitamin D2 on calcium homeostasis in postmenopausal osteopenic women. J. Bone Miner. Res. 1994, 9, 607-614. [CrossRef]

76. Miliku, K.; Voortman, T.; Franco, O.H.; McGrath, J.J.; Eyles, D.W.; Burne, T.H.; Hofman, A.; Tiemeier, H.; Jaddoe, V.W. Vitamin D status during fetal life and childhood kidney outcomes. Eur. J. Clin. Nutr. 2016, 70, 629-634. [CrossRef]

77. Atkinson, M.A.; Melamed, M.L.; Kumar, J.; Roy, C.N.; Miller, E.R.; Furth, S.L.; Fadrowski, J.J. Vitamin D, Race, and Risk for Anemia in Children. J. Pediatr. 2014, 164, 153-158.e1. [CrossRef]

78. Lerch, C.; Shroff, R.; Wan, M.; Rees, L.; Aitkenhead, H.; Bulut, I.K.; Thurn, D.; Bayazit, A.K.; Niemirska, A.; Canpolat, N.; et al. Effects of nutritional vitamin D supplementation on markers of bone and mineral metabolism in children with chronic kidney disease. Nephrol. Dial. Transplant. 2018, 33, 2208-2217. [CrossRef] [PubMed] 
79. Doyon, A.; Fischer, D.-C.; Bayazit, A.K.; Canpolat, N.; Duzova, A.; Sözeri, B.; Bacchetta, J.; Balat, A.; Büscher, A.; Candan, C.; et al. Markers of Bone Metabolism Are Affected by Renal Function and Growth Hormone Therapy in Children with Chronic Kidney Disease. PLoS ONE 2015, 10, e0113482. [CrossRef]

80. Naumova, V.I.; Rusnak, F.I.; Vereskova, S.A.; Kutafina, E.K.; Panchenko, E.L. Primenenie vitamina D2 i ego metabolitov pri khronicheskom glomerulonefrite u deter [Use of vitamin D 2 and its metabolites in chronic glomerulonephritis in children]. Pediatriia 1989, 5, 19-22.

81. Conti, G.; Chirico, V.; Lacquaniti, A.; Silipigni, L.; Fede, C.; Vitale, A.; Fede, C. Vitamin D intoxication in two brothers: Be careful with dietary supplements. J. Pediatr. Endocrinol. Metab. 2014, 27. [CrossRef] [PubMed]

82. Kalkwarf, H.J.; Denburg, M.R.; Strife, C.F.; Zemel, B.S.; Foerster, D.L.; Wetzsteon, R.J.; Leonard, M.B. Vitamin D deficiency is common in children and adolescents with chronic kidney disease. Kidney Int. 2012, 81, 690-697. [CrossRef]

83. Shroff, R.; Wan, M.; Nagler, E.V.; Bakkaloğlu, S.; Fischer, D.-C.; Bishop, N.; Cozzolino, M.; Bacchetta, J.; Edefonti, A.; Stefanidis, C.J.; et al. Clinical practice recommendations for native vitamin D therapy in children with chronic kidney disease Stages $2-5$ and on dialysis. Nephrol. Dial. Transplant. 2017, 32, 1098-1113. [CrossRef]

84. Shroff, R.; Aitkenhead, H.; Costa, N.; Trivelli, A.; Litwin, M.; Picca, S.; Anarat, A.; Sallay, P.; Ozaltin, F.; Zurowska, A.; et al. Normal 25-Hydroxyvitamin D Levels Are Associated with Less Proteinuria and Attenuate Renal Failure Progression in Children with CKD. J. Am. Soc. Nephrol. 2016, 27, 314-322. [CrossRef] [PubMed]

85. Misra, M.; Pacaud, D.; Petryk, A.; Collett-Solberg, P.F.; Kappy, M. Drug and therapeutics committee of the Lawson Wilkins Pediatric Endocrine Society: Vitamin D deficiency in children and its management: Review of current knowledge and recommendations. Pediatrics 2008, 122, 398-417. [CrossRef] [PubMed]

86. Wagner, C.L.; Greer, F.R. Prevention of rickets and vitamin D deficiency in infants, children, and adolescents. Pediatrics 2008, 122, 1142-1152. [CrossRef] [PubMed]

87. Noone, D.G.; Iijima, K.; Parekh, R. Idiopathic nephrotic syndrome in children. Lancet 2018, 392, 61-74, Erratum in 2018, 392, 282. [CrossRef]

88. Nielsen, C.A.; Jensen, J.E.; Cortes, D. Vitamin D status is insufficient in the majority of children at diagnosis of nephrotic syn-drome. Dan. Med. J. 2015, 62, A5017.

89. Pańczyk-Tomaszewska, M.; Mizerska-Wasiak, M.; Ziółkowska, H.; Adamczuk, D.; Kisiel, A.; Wawer, Z.; Kamińska, A.; Roszkowska-Blaim, M. Zasoby witaminy D u dzieci chorobami nerek [Vitamin D status in children with renal diseases]. Med. Wieku Rozwoj. 2013, 17, 306-312.

90. Zaniew, M.; Jarmoliński, T. Vitamin D status and bone density in steroid-treated children with glomerulopathies: Effect of cholecalciferol and calcium supplementation. Adv. Med. Sci. 2012, 57, 88-93. [CrossRef]

91. Cantorna, M.T.; Snyder, L.; Lindsay, S.; Yang-Ding, L. Vitamin D and 1,25(OH)2D Regulation of T cells. Nutrients 2015, 7, 3011-3021. [CrossRef]

92. Sergeev, I.N.; Pletsityŭ, K.D.; Rusnak, F.I.; Spirichev, V.B. Razvitie D-vitaminnoŭ nedostatochnosti i immunologicheskikh narusheniǔ pri glomerulonefrite $\mathrm{u}$ detě [Development of vitamin D deficiency and immunologic disorders in children with glomerulonephritis]. Vopr Pitan. 1990, 4, 28-31.

93. Cantorna, M.T. Why do T cells express the vitamin D receptor? Ann. N. Y. Acad. Sci. 2011, 1217, 77-82. [CrossRef] [PubMed]

94. White, P.; Cooke, N. The Multifunctional Properties and Characteristics of Vitamin D-binding Protein. Trends Endocrinol. Metab. 2000, 11, 320-327. [CrossRef]

95. Newton, D.A.; Baatz, J.E.; Kindy, M.S.; Gattoni-Celli, S.; Shary, J.R.; Hollis, B.W.; Wagner, C.L. Vitamin D binding protein polymorphisms significantly impact vitamin D status in children. Pediatr. Res. 2019, 86, 662-669. [CrossRef] [PubMed]

96. Madden, K.; Feldman, H.A.; Chun, R.F.; Smith, E.M.; Sullivan, R.M.; Agan, A.A.; Keisling, S.M.; Panoskaltsis-Mortari, A.; Randolph, A.G. Critically Ill Children Have Low Vitamin D-Binding Protein, Influencing Bioavailability of Vitamin D. Ann. Am. Thorac. Soc. 2015, 12, 1654-1661. [CrossRef]

97. Nykjaer, A.; Dragun, D.; Walther, D.; Vorum, H.; Jacobsen, C.; Herz, J.; Melsen, F.; Christensen, E.I.; E Willnow, T. An Endocytic Pathway Essential for Renal Uptake and Activation of the Steroid 25-(OH) Vitamin D3. Cell 1999, 96, 507-515. [CrossRef]

98. Gordon, C.M.; Feldman, H.A.; Sinclair, L.; Williams, A.L.; Kleinman, P.K.; Perez-Rossello, J.; Cox, J.E. Prevalence of Vitamin D Deficiency Among Healthy Infants and Toddlers. Arch. Pediatr. Adolesc. Med. 2008, 162, 505-512. [CrossRef] [PubMed]

99. Dahl, B.; Schiødt, F.V.; Ott, P.; Wians, F.; Lee, W.M.; Balko, J.; O’Keefe, G.E. Plasma concentration of Gc-globulin is associated with organ dysfunction and sepsis after injury. Crit. Care Med. 2003, 31, 152-156. [CrossRef]

100. Bennett, M.R.; Pordal, A.; Haffner, C.; Pleasant, L.; Ma, Q.; Devarajan, P. Urinary Vitamin D-Binding Protein as a Biomarker of Steroid-Resistant Nephrotic Syndrome. Biomark. Insights 2016, 11, 1-6. [CrossRef]

101. Bennett, M.R.; Pleasant, L.; Haffner, C.; Ma, Q.; Haffey, W.D.; Ying, J.; Wagner, M.; Greis, K.D.; Devarajan, P. A Novel Biomarker Panel to Identify Steroid Resistance in Childhood Idiopathic Nephrotic Syndrome. Biomark. Insights 2017, 12. [CrossRef] [PubMed]

102. Rajappa, M.; Choudhary, A.; Mohanraj, P.S.; Krishnamurthy, S. Association of Urinary Vitamin D Binding Protein and Neutrophil Gelatinase-Associated Lipocalin with Steroid Responsiveness in Idiopathic Nephrotic Syndrome of Childhood. Saudi J. Kidney Dis. Transplant. 2020, 31, 946-956. [CrossRef] [PubMed]

103. Gembillo, G.; Cernaro, V.; Siligato, R.; Curreri, F.; Catalano, A.; Santoro, D. Protective Role of Vitamin D in Renal Tubulopathies. Metabolites 2020, 10, 115. [CrossRef] 
104. Chapron, B.D.; Chapron, A.; Phillips, B.; Okoli, M.C.; Shen, D.D.; Kelly, E.J.; Himmelfarb, J.; Thummel, K.E. Reevaluating the role of megalin in renal vitamin D homeostasis using a human cell-derived microphysiological system. Altex 2018, 35, 504-515. [CrossRef]

105. Santoro, D.; Buemi, M.; Gagliostro, G.; Vecchio, M.; Currò, M.; Ientile, R.; Caccamo, D. Association of VDR gene polymorphisms with heart disease in chronic kidney disease patients. Clin. Biochem. 2015, 48, 1028-1032. [CrossRef] [PubMed]

106. Yang, S.; Li, A.; Wang, J.; Liu, J.; Han, Y.; Zhang, W.; Li, Y.C.; Zhang, H. Vitamin D Receptor: A Novel Therapeutic Target for Kidney Diseases. Curr. Med. Chem. 2018, 25, 3256-3271. [CrossRef]

107. Santoro, D.; Caccamo, D.; Gagliostro, G.; Ientile, R.; Benvenga, S.; Bellinghieri, G.; Savica, V. Vitamin D metabolism and activity as well as genetic variants of the vitamin D receptor (VDR) in chronic kidney disease patients. J. Nephrol. 2012, 26, 636-644. [CrossRef]

108. Santoro, D.; Gagliostro, G.; Alibrandi, A.; Ientile, R.; Bellinghieri, G.; Savica, V.; Buemi, M.; Caccamo, D. Vitamin D Receptor Gene Polymorphism and Left Ventricular Hypertrophy in Chronic Kidney Disease. Nutrients 2014, 6, 1029-1037. [CrossRef]

109. Ozaki, Y.; Nomura, S.; Nagahama, M.; Yoshimura, C.; Kagawa, H.; Fukuhara, S. Vitamin-D receptor genotype and renal dis-order in Japanese patients with systemic lupus erythematosus. Nephron 2000, 85, 86-91. [CrossRef]

110. Mahyar, A.; Ayazi, P.; Afshar, A.S.; Farivar, T.N.; Sahmani, M.; Oveisi, S.; Shabani, R.; Esmaeili, S. Vitamin D receptor gene (FokI, TaqI, BsmI, and ApaI) polymorphisms in children with urinary tract infection. Pediatr. Res. 2018, 84, 527-532. [CrossRef]

111. Jafar, T.; Tripathi, G.; Mehndi, A.A.; Mandal, K.; Gulati, S.; Sharma, R.K.; Baburaj, V.P.; Awasthi, S.; Agrawal, S. Vitamin D Receptor Gene Polymorphisms in Indian Children with Idiopathic Nephrotic Syndrome. Int. J. Hum. Genet. 2009, 9, 49-55. [CrossRef]

112. Al-Eisa, A.; Haider, M.Z. Vitamin D receptor gene TaqI and Apal polymorphisms and steroid responsiveness in childhood idiopathic nephrotic syndrome. Int. J. Nephrol. Renov. Dis. 2016, 9, 187-192. [CrossRef]

113. Wyatt, R.J.; Julian, B.A. IgA Nephropathy. N. Engl. J. Med. 2013, 368, 2402-2414. [CrossRef]

114. Li, X.H.; Huang, X.P.; Pan, L.; Wang, C.Y.; Qin, J.; Nong, F.W.; Luo, Y.Z.; Wu, Y.; Huang, Y.M.; Peng, X.; et al. Vitamin D deficiency may predict a poorer outcome of IgA nephropathy. BMC Nephrol. 2016, 17, 164. [CrossRef]

115. Reich, H.N.; Troyanov, S.; Scholey, J.W.; Cattran, D.C. Remission of proteinuria improves prognosis in IgA nephropathy. J. Am. Soc. Nephrol. 2007, 18, 3177-3183. [CrossRef]

116. Radhakrishnan, J.; Cattran, D.C. The KDIGO practice guideline on glomerulonephritis: Reading between the (guide) linesapplication to the individual patient. Kidney Int. 2012, 82, 840-856. [CrossRef]

117. Humalda, J.K.; Goldsmith, D.J.A.; Thadhani, R.; De Borst, M.H. Vitamin D analogues to target residual proteinuria: Potential impact on cardiorenal outcomes. Nephrol. Dial. Transplant. 2015, 30, 1988-1994. [CrossRef] [PubMed]

118. De Borst, M.H.; Hajhosseiny, R.; Tamez, H.; Wenger, J.; Thadhani, R.; Goldsmith, D.J.A. Active Vitamin D Treatment for Reduction of Residual Proteinuria: A Systematic Review. J. Am. Soc. Nephrol. 2013, 24, 1863-1871. [CrossRef]

119. Xiaowei, L.; Bo, W.; Li, L.; Peng, Z. Comparison of the effects of valsartan plus activated vitamin D versus valsartan alone in IgA nephropathy with moderate proteinuria. Int. Urol. Nephrol. 2020, 52, 129-136. [CrossRef]

120. Szeto, C.C.; Chow, K.M.; Kwan, B.C. Oral calcitriol for the treatment of persistent proteinuria in immunoglobulin A nephropathy: An uncontrolled trial. Am. J. Kidney Dis. 2008, 51, 724-731. [CrossRef]

121. Deng, J.; Zheng, X.; Xie, H.; Chen, L. Calcitriol in the treatment of IgA nephropathy with non-nephrotic range proteinuria: A meta-analysis of randomized controlled trials. Clin. Nephrol. 2017, 87, 21-27. [CrossRef]

122. Mann, M.C.; Hemmelgarn, B.R.; Exner, D.V.; Hanley, D.A.; Turin, T.C.; Wheeler, D.C.; Sola, D.Y.; Ellis, L.; Ahmed, S.B. Vitamin D Supplementation Is Associated With Stabilization of Cardiac Autonomic Tone in IgA Nephropathy. Hypertension $2015,66$. [CrossRef]

123. DeLuca, G.C.; Kimball, S.M.; Kolasinski, J.; Ramagopalan, S.V.; Ebers, G.C. Review: The role of vitamin D in nervous system health and disease. Neuropathol. Appl. Neurobiol. 2013, 39, 458-484. [CrossRef]

124. Pilz, S.; Tomaschitz, A.; Drechsler, C.; Dekker, J.M.; März, W. Vitamin D deficiency and myocardial diseases. Mol. Nutr. Food Res. 2010, 54, 1103-1113. [CrossRef]

125. Zeng, J.; Wen, Q.; Rong, R.; Huang, F.; Yang, Q.; Tang, X.; He, F.; Huang, N.; Yu, X. Vitamin D-Binding Protein Is a Potential Urinary Biomarker of Irbesartan Treatment Response in Patients with IgA Nephropathy. Genet. Test. Mol. Biomarkers 2016, 20, 666-673. [CrossRef] [PubMed]

126. Shi, M.; Ouyang, Y.; Yang, M.; Yang, M.; Zhang, X.; Huang, W.; Wang, W.; Wang, Z.; Zhang, W.; Chen, X.; et al. IgA Nephropathy Susceptibility Loci and Disease Progression. Clin. J. Am. Soc. Nephrol. 2018, 13, 1330-1338. [CrossRef] [PubMed]

127. Mo, M.-Q.; Pan, L.; Tan, L.; Jiang, L.; Pan, Y.-Q.; Li, F.-J.; Yang, Z.-H.; Liao, Y.-H. Association between VDR gene FokI polymorphism and renal function in patients with IgA nephropathy. PeerJ 2019, 7, e7092. [CrossRef] [PubMed]

128. Yang, L.; Ma, J.; Zhang, X.; Fan, Y.; Wang, L. Protective role of the vitamin D receptor. Cell. Immunol. 2012, 279, 160-166. [CrossRef]

129. Rovin, B.; Bomback, A.; Radhakrishnan, J. Chapter 41-Lupus Nephritis. In Chronic Renal Disease; Academic Press: Cambridge, MA, USA, 2015; pp. 501-512. ISBN 9780124116023. [CrossRef]

130. Alarcón, G.S. Multiethnic lupus cohorts: What have they taught us? Reumatología Clínica 2011, 7, 3-6. [CrossRef]

131. Sumethkul, K.; Boonyaratavej, S.; Kitumnuaypong, T.; Angthararuk, S.; Cheewasat, P.; Manadee, N.; Sumethkul, V. The predictive factors of low serum 25-hydroxyvitamin D and vitamin D deficiency in patients with systemic lupus erythematosus. Rheumatol. Int. 2013, 33, 1461-1467. [CrossRef] 
132. Lin, T.C.; Wu, J.Y.; Kuo, M.L.; Ou, L.S.; Yeh, K.W.; Huang, J.L. Correlation between disease activity of pediatric-onset systemic lupus erythematosus and level of vitamin D in Taiwan: A case-cohort study. J. Microbiol. Immunol. Infect. 2018, 51, 110-114. [CrossRef]

133. Yu, Q.; Qiao, Y.; Liu, D.; Liu, F.; Gao, C.; Duan, J.; Liang, L.; Di, X.; Yuan, Y.; Gao, Y.; et al. Vitamin D protects podocytes from autoantibodies induced injury in lupus nephritis by reducing aberrant autophagy. Arthritis Res. Ther. 2019, 21, 19. [CrossRef]

134. Pérez-Ferro, M.; Romero-Bueno, F.I.; Serrano Del Castillo, C.; Mahillo, I.; Alvear, A.; Largo, R.; Herrero-Beaumont, G.; SánchezPernaute, O. A subgroup of lupus patients with nephritis, innate T cell activation and low vitamin D is identified by the enhancement of circulating MHC class I-related chain A. Clin. Exp. Immunol. 2019, 196, 336-344. [CrossRef]

135. Kizildag, S.; Ates, H.; Kizildag, S. Treatment of K562 cells with 1,25-dihydroxyvitamin D3 induces distinct alterations in the expression of apoptosis-related genes BCL2, BAX, BCLXL, and p21. Ann. Hematol. 2010, 89, 1-7. [CrossRef]

136. Umar, M.; Sastry, K.S.; Chouchane, A.I. Role of Vitamin D Beyond the Skeletal Function: A Review of the Molecular and Clinical Studies. Int. J. Mol. Sci. 2018, 19, 1618. [CrossRef] [PubMed]

137. Terrier, B.; Derian, N.; Schoindre, Y.; Chaara, W.; Geri, G.; Zahr, N.; Mariampillai, K.; Rosenzwajg, M.; Carpentier, W.; Musset, L.; et al. Restoration of regulatory and effector $\mathrm{T}$ cell balance and $\mathrm{B}$ cell homeostasis in systemic lupus erythematosus patients through vitamin D supplementation. Arthritis Res. Ther. 2012, 14, R221. [CrossRef]

138. Zhou, T.B.; Jiang, Z.P.; Lin, Z.J.; Su, N. Association of vitamin D receptor gene polymorphism with the risk of systemic lupus erythematosus. J. Recept Signal. Transduct. Res. 2015, 35, 8-14. [CrossRef] [PubMed]

139. Emerah, A.A.; El-Shal, A.S. Role of vitamin D receptor gene polymorphisms and serum 25-hydroxyvitamin D level in Egyptian female patients with systemic lupus erythematosus. Mol. Biol. Rep. 2013, 40, 6151-6162. [CrossRef] [PubMed]

140. Mostowska, A.; Lianeri, M.; Wudarski, M.; Olesińska, M.; Jagodziński, P.P. Vitamin D receptor gene BsmI, FokI, ApaI and TaqI polymorphisms and the risk of systemic lupus erythematosus. Mol. Biol. Rep. 2013, 40, 803-810. [CrossRef]

141. Azab, S.F.; Ali, Y.F.; Farghaly, M.A.; Hamed, M.E.; Allah, M.A.; Emam, A.A.; Abdelsalam, N.I.; Hashem, M.I.; Gawish, H.H.; Nabil, R.M.; et al. Vitamin D receptor gene BsmI polymorphisms in Egyptian children and adolescents with systemic lupus erythematosus: A case-control study. Medicine 2016, 95, e5233. [CrossRef]

142. Imam, A.A.; Ibrahim, H.E.; Farghaly, M.A.A.; Alkholy, U.M.; Gawish, H.H.; Abdalmonem, N.; Sherif, A.M.; Ali, Y.F.; Hamed, M.E.; Waked, N.M.; et al. Vitamin D receptor gene FokI polymorphism in Egyptian children and adolescents with SLE: A case-control study. Lupus 2017, 26, 1426-1434. [CrossRef]

143. Mahto, H.; Tripathy, R.; Das, B.K.; Panda, A.K. Association between vitamin D receptor polymorphisms and systemic lupus erythematosus in an Indian cohort. Int. J. Rheum. Dis. 2018, 21, 468-476. [CrossRef]

144. Luo, X.Y.; Yang, M.H.; Wu, F.X.; Wu, L.J.; Chen, L.; Tang, Z.; Liu, N.T.; Zeng, X.F.; Guan, J.L.; Yuan, G.H. Vitamin D receptor gene BsmI polymorphism B allele, but not BB genotype, is associated with systemic lupus erythematosus in a Han Chinese population. Lupus 2012, 21, 53-59. [CrossRef]

145. Sun, J.; Zhang, S.; Liu, J.S.; Gui, M.; Zhang, H. Expression of vitamin D receptor in renal tissue of lupus nephritis and its association with renal injury activity. Lupus 2019, 28, 290-294. [CrossRef]

146. Brunner, H.I.; Bennett, M.R.; Gulati, G.; Abulaban, K.; Klein-Gitelman, M.S.; Ardoin, S.P.; Tucker, L.B.; Rouster-Stevens, K.A.; Witte, D.; Ying, J.; et al. Urine Biomarkers to Predict Response to Lupus Nephritis Therapy in Children and Young Adults. J. Rheumatol. 2017, 44, 1239-1248. [CrossRef] [PubMed]

147. Go, D.J.; Lee, J.Y.; Kang, M.J.; Lee, E.Y.; Lee, E.B.; Yi, E.C.; Song, Y.W. Urinary vitamin D-binding protein, a novel biomarker for lupus nephritis, predicts the development of proteinuric flare. Lupus 2018, 27, 1600-1615. [CrossRef]

148. Donate-Correa, J.; Domínguez-Pimentel, V.; Méndez-Pérez, M.L.; Muros-de-Fuentes, M.; Mora-Fernández, C.; Martín-Núñez, E.; Cazaña-Pérez, V.; Navarro-González, J.F. Selective vitamin D receptor activation as anti-inflammatory target in chronic kidney disease. Mediators Inflamm. 2014, 2014, 670475. [CrossRef] 